\title{
Authors' reply: Distinguishing between hantavirus- induced haemorrhagic fever with renal syndrome and pregnancy-induced liver pathologies (AFLP and HELLP syndromes)
}

G Macé ${ }^{1}$, M Henaff $^{1}$, A S Gobenceaux ${ }^{1}$, C Feyeux ${ }^{1}$, P Sagot ${ }^{1}$, J M Reynes (jean-marc.reynes@inserm.fr) ${ }^{2}$

1. Department of Obstetrics and Gynecology, Centre Hospitalier Universitaire (CHU) Bocage, Burgundy University, Dijon, France

2. Centre National de Référence des Hantavirus, Unité de Biologie des Infections Virales Emergentes, Institut Pasteur, Lyon, France

To the editor:

We thank Clement et al. for their interest in our work [1] and for questioning the diagnostic sequence and management of such a complex clinical and biological situation. During pregnancy, diagnosis of haemorrhagic fever with renal syndrome (HFRS) caused by hantaviruses, including Seoul virus (SEOV), can easily be missed due to its rarity and its 'pseudo-vasculoplacental' clinical presentation. Distinguishing between hantavirus infection and certain liver pathologies of pregnancy, especially severe preeclampsia with haemolysis, elevated liver enzymes and low platelet count (HELLP) syndrome and acute fatty liver of pregnancy (AFLP), can be problematic.

While hantavirus infection can biologically mimic HELLP syndrome - because of proteinuria and the biological triad anaemia-thrombocytopenia-elevated levels of liver enzymes - its presentation and natural history are different. In a hantavirus-induced syndrome, viral symptoms are most noticeable, while hypertension can appear only secondarily. Anaemia occurs in the later stages of the infection and renal failure (interstitial nephritis) dominates the biological picture. Regarding AFLP, there are clearly clinical and biological similarities with hantavirus infection, even if AFLP preferentially occurs in women in the third trimester of pregnancy whereas hantavirus infection can be observed throughout pregnancy. The initial symptoms are common digestive disorders. Jaundice is common in AFLP and absent in hantavirus infection. Hypertension and hyperthermia may be observed in both AFLP and hantavirus infection. Biologically, renal failure, elevated levels of liver enzymes, thrombocytopenia and coagulation abnormalities are also frequent in both pathologies [2-7]. The Table synthesises the principal similarities between the three pathologies.
As pointed out by Clement et al. [1], fetal and maternal prognosis is highly dependent on the therapeutics used and in such confusing cases during pregnancy, and aetiological distinction before decision-making can be very difficult.

In AFLP or HELLP syndrome, emergency delivery is the only treatment, whereas in HFRS, continuation of pregnancy and symptomatic treatment are possible, thus avoiding neonatal prematurity without compromising maternal renal function. However, a dramatic reduction in renal function, or particular conditions such as a single kidney, could lead to a more aggressive management, as described in our case [8].

We agree with Clement et al. that the knowledge of clinical and biological natural history can help, to some extent, to discriminate between the possible diagnoses and evoke SEOV infection (especially normalisation of coagulopathy before renal failure), but obstetric decision-making must also take into account the worst probable outcome when the mother's health is at stake. Firstly, contrary to what has been suggested by Clement et al., alkaline phosphatase and bilirubin rates cannot be interpreted during pregnancy and we consider that the 'lipid paradox' is not relevant in an urgent situation. Secondly, SEOV infection has a quite reproducible pattern - initially with thrombocytopenia, then elevated levels of liver enzymes and finally transitory renal failure at the end of the illness [9] - which is not the case for HELLP and AFLP. Indeed, renal function can deteriorate dramatically in persons with HELLP or AFLP condition, potentially leading to terminal failure. Thus, if there is a rapid increase in the level of serum creatinine, waiting for the renal function to recover is risky when fetal extraction might restore the mother to health. 
Clinical and biological profiles of Seoul hantavirus-induced HFRS, AFLP and HELLP syndrome

\begin{tabular}{|c|c|c|c|}
\hline \multirow[b]{2}{*}{ Profile } & \multicolumn{3}{|c|}{ Prevalence of symptom or condition in affected patients (\%) } \\
\hline & $\begin{array}{c}\text { Seoul hantavirus-induced } \\
\text { HFRS }\end{array}$ & AFLP & HELLP syndrome \\
\hline \multicolumn{4}{|l|}{ Physical symptoms } \\
\hline Fever & 100 & $25-32$ & 0 \\
\hline Headaches & $70-89$ & ND & 50 \\
\hline Myalgia & $56-73$ & ND & ND \\
\hline Retro-orbital pain & $43-68$ & ND & ND \\
\hline Back pain & $58-85$ & ND & ND \\
\hline Digestive symptoms & 100 & ND & ND \\
\hline Nausea/vomiting & 88 & 70 & 40 \\
\hline Abdominal pain & $62-68$ & $35-50$ & $60-80$ \\
\hline Diarrhoea & 33 & ND & ND \\
\hline Hot flushes & $41-78$ & ND & ND \\
\hline Neurological signs & $17-23$ & $30-40$ & $40-60$ \\
\hline Hypertension & ND & 50 & 85 \\
\hline \multicolumn{4}{|l|}{ Biological findings } \\
\hline Haemolysis & o & $15-20$ & $50-100$ \\
\hline Proteinuria & 78 & $30-50$ & $90-95$ \\
\hline Hyperleucocytosis & 72 & ND & ND \\
\hline Thrombopenia & 82 & 100 & 100 \\
\hline Hepatic cytolysis & $70-88$ & 100 & 100 \\
\hline Renal failure & $57-77$ & $90-100$ & 50 \\
\hline Coagulopathy (DIC or abnormal prothrombin time) & 100 & 73 & $<20$ \\
\hline
\end{tabular}

AFLP: acute fatty liver of pregnancy; DIC: disseminated intravascular coagulation; HELLP: haemolysis, elevated liver enzymes and low platelet count; HFRS: haemorrhagic fever with renal syndrome; ND: not described.

Source: Seoul hantavirus-induced HFRS [9-11], AFLP $[6,7]$, HELLP syndrome $[6,7]$.

On the other hand, if one is aware of the similarities of these aetiologies, patients could be asked about hantaviral risk factors and a hantavirus serological IgM rapid-test, if available, could be requested once inflammatory biological syndrome (elevated C-reactive protein, elevated levels of liver enzymes) with coagulopathy occurs, while renal function is still correct or only moderately altered. This means that the observation period leading to diagnosis is very limited. When renal failure with proteinuria occurs, unless it has been clearly demonstrated that there is a hantavirus infection in another person living in the same environment, or in case of positive hantavirus rapid test, we suggest not to delay the delivery.
Conflict of interest

None declared.

Authors' contributions

Guillaume Macé wrote the letter. All co-authors reviewed the letter. 


\section{References}

1. Clement J, Vergote V, Laenen L, Van Ranst M. Letter to the editor: Distinguishing between hantavirus-induced haemorrhagic fever with renal syndrome and pregnancyinduced liver pathologies (AFLP and HELLP syndromes). Euro Surveill. 2013;18(22):pii=20493. Available from: http://www. eurosurveillance.org/ViewArticle.aspx?Articleld=20493

2. Bacq Y. [Acute fatty liver in pregnancy]. Gastroenterol Clin Biol. 1997;21(2):109-15. French. PMid:9161476

3. Homer L, Hebert T, Nousbaum JB, Bacq Y, Collet M. [How to confirm acute fatty liver of pregnancy in case of emergency]. Gynecol Obstet Fertil. 2009;37(3):246-51. French. http:// dx.doi.org/10.1016/j.gyobfe.2008.11.016 PMid:19246234

4. Dedecker F, Graesslin O, Palot M, Fortier D, Quéreux C, Gabriel R. [Acute fatty liver of pregnancy: a rare pathology of the third trimester]. Gynecol Obstet Fertil. 2006;34(2):1313. French. http://dx.doi.org/10.1016/j.gyobfe.2005.10.028 PMid:16442327

5. Bacq Y, Assor P, Gendrot C, Perrotin F, Scotto B, Andres C. [Recurrent acute fatty liver of pregnancy]. Gastroenterol Clin Biol. 2007;31(12):1135-8. French. http://dx.doi.org/10.1016/ So399-8320(07)78351-3

6. Sibai BM. Imitators of severe preeclampsia. Obstet Gynecol. 2007:109(4):956-66. http://dx.doi.org/10.1097/01. AOG.0000258281.22296.de PMid: 17400860

7. Vigil-De Gracia P. Acute fatty liver and HELLP syndrome: two distinct pregnancy disorders. Int J Gynaecol Obstet. 2001;73(3):215-20. http://dx.doi.org/10.1016/S0020-7292(01)00364-2

8. Macé G, Feyeux C, Mollard N, Chantegret C, Audia S, Rebibou JM, et al. Severe Seoul hantavirus in a pregnant woman, France, October 2012. Euro Surveill. 2013;18(17): pii=20464. Available from: http://www.eurosurveillance.org/ViewArticle. aspx?Articleld $=20464$ PMid:23647626

9. Kim YS, Ahn C, Han JS, Kim S, Lee JS, Lee PW. Hemorrhagic fever with renal syndrome caused by the Seoul virus. Nephron. 1995;71(4):419-427. http://dx.doi.org/10.1159/000188762 PMid:8587622

10. Zhang X, Chen HY, Zhu LY, Zeng LL, Wang F, Li QG, et al. Comparison of Hantaan and Seoul viral infections among patients with hemorrhagic fever with renal syndrome (HFRS) in Heilongjiang, China. Scand J Infect Dis. 2011;43(8):632-41. http://dx.doi.org/10.3109/00365548.2011.566279 PMid:21428852

11. Lee M. Coagulopathy in patients with hemorrhagic fever with renal syndrome. J Korean Med Sci. 1987;2(4):201-11 PMid:3151765 PMCid:3053648 